\title{
Cisplatin が有効であった
}

下咽頭腫焬の一例

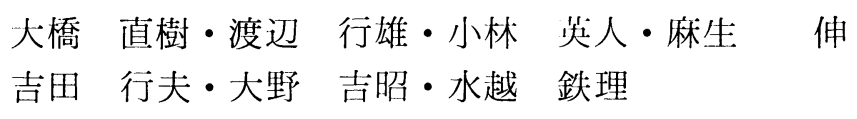

\section{A Case of Hypopharyngeal Carcinoma Having Remarkable Remission due to Gisplatin Therapy}

\author{
Naoki Ohashi, Yukio Watanabe, Hideto Kobayashi, \\ Shin Aso, Yukio Yoshida, Yoshiaki Ohno, Kanemasa Mizukoshi \\ (Toyama Medical \& Pharmaceutical Universty)
}

A 70 year-old female visited our department because of dysphagia. Laryngoscopic and X-ray examinations revealed a large tumor which stemmed from the posterior wall of the hypopharynx and spread into the bilateral pyriform sinuses. Radical operation was not considered to be indicated because of her age and she was treated with Cisplatin.

Cisplatin, $20 \mathrm{mg} / \mathrm{m}^{2} /$ day, was administered intravenously for five days with PEP, $6 \mathrm{mg} / \mathrm{m}^{2} /$ day, and sufficient hydration of $3000 \mathrm{ml}$ a day.

The sensation of dysphagia disappeared and laryngoscopic and X-ray examinations showed almost complete remission of the tumor after this treatment.

Several side effects of Cisplatin such as renal failure, myelosupression, hearing impairment and so on have been reported. However, if patients are selected and hydration is sufficient, maximum anti-cancer effect can be expected of Cisplatin with minimal side effects.

\section{はじめに}

下咽頭腫瘍は，湏頸部領域の悪性腫瘍の中では， 5 年粗生存率が平均10〜20\%と最屯予後不良な 悪性腫瘍である，又治療成績のためには照射と手術療法による拡大根治療法が一般的に行われてい $3^{1)}$.

私達は, 高年令と腫瘍容積が大きいために一般的に行われている照射＋手術療法では根治は困難 と判断した下咽頭腫瘍例に対して, Cisplatin を中心とした化学療法を行った. 1クール終了後に 間接喉頭鏡下及び各種レントゲン検査で，ほぼ完全な腫瘍の消失をみたので報告する. 
症

症例は 74 才の众性であり，昭和57年 2 月頃よ り曣下障害が生じ，同年 3 月に当科外来を受診 した。初㡣時に，間接喉頭鏡検査で，下咽頭に 腫瘍が認められたので，至急入院となった，家 族歴，既往歴には特に異常は認められなかっ た。頸部単純レントゲン写真, 下㕧頭造影等のの 検査で, 左下栶頭後壁から生じ，左梨状陥川か

\section{例}

ら右梨状陥川に及ぶ「大な腫湯が認められ， 又, 頸部リンパ邻転移及び遠隔転移は認めなか ったので, $\mathrm{T}_{3} \mathrm{~N}_{0} \mathrm{M}_{0}$ の下咽頭腫瘍と診断した. 高令之腫瘍容積が大きいために手術療法は不可 能と判断し Cisplatin を中心とした化学療法 を行うことに決定した。尚, 病理検査では, 分化した扁怆波癌であった。

\section{Cisplatin の投与方法}

表 1 には, 今回私達の行った化学療法の施行 方法を示した. Cisplatinは重金属のために腎 に沈着し腎障害を起こすととが最大の副作用で あり, Cisplatin 療法の特徵は，十分な利尿を つけるととにある。そこでCisplatin 投与に先 立って 1 日 $3000 \mathrm{ml}$ の補液を 2 日間行い利尿を促 進させた。次に同様に 1 日 $3000 \mathrm{ml}$ の補液と $90 \mathrm{ml}$ のマンニトールの投与と共に, 体表面積 $1 \mathrm{~m}^{2}$ あ たり 1 日20mgの Cisplatin と体表面積 $1 \mathrm{~m}^{2}$ あ

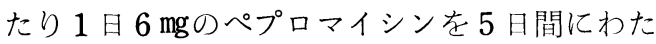
り静注した。 又, ペプロマイシンの副作用であ る肺繊維症の予防としてプレドニン $20 \mathrm{mg}$ を経 で投与した. Cisplatin 投与後も更に 4 日間は $3000 \mathrm{ml}$ 又は $1000 \mathrm{ml}$ の補液を続けた。

この方法を 1 クール行ったところ, 間接喉頭 鏡検査での腫瘍の消失之, 嬿下障害の改善及び 頸部レントゲン写真, 下咽頭造影での腫瘍のほ ぼ完全な消失が認められた。図 $1 ， 2 ， 3$ は， 頸部レントゲン側面像, 下咽頭造影心:面像, 側 面像を示しており，いずれも左が，Cisplatin

投与前，右が投与後の状態を示している．乙れ らの検査からは，ほぼ完全に腫瘍は消失してい た。引き続いて行った内視鏡検査では，左下咽 頭後壁に約 $0.5 \mathrm{~cm} \times 1.0 \mathrm{~cm}$ の腫瘍の残存が認めら れたため,リニアック照射5000radsを行ったと こ万，腫瘍は内視鏡的にも消失し，玩在経過を 觀察中である。

表 I

Cisplatin +PEP療法

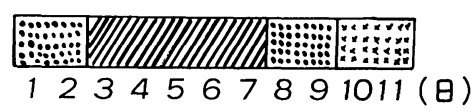

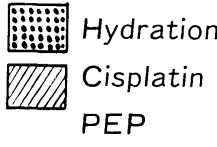

Hydration

Mannitol

Predonine

Hydration

$3000 \mathrm{ml} / \mathrm{\theta}$
$20 \mathrm{mg} / \mathrm{M}^{2} / \mathrm{\theta}$
$6 \mathrm{mg} / \mathrm{M}^{2} / \mathrm{\theta}$
$3000 \mathrm{ml} / \mathrm{\theta}$
$90 \mathrm{ml} / \mathrm{\theta}$
$20 \mathrm{mg} / \mathrm{\theta}$ (peros)
$1000 \mathrm{ml} / \mathrm{\theta}$

\section{Cisplatin の副作用と予防法}

Cisplatin の副作用には腎障害, 造血障害, 聴力障害及び消化器障害等が報告されている （表 2 ）。腎障害は重金属プラチナによる急性細 尿管壊死によるものであり, 血清 $\mathrm{K}, \mathrm{BUN}$ 的 上昇やクレアチニンの上昇が認められ, 又 P S $\mathrm{P}$, クレアチニンクリアランスの低下が生じる とされている。腎障害は体表面積 $1 \mathrm{~m}^{2}$ あたり 50mgの Cisplatin 投与.では28〜36\%に発生が 認められ, 投与後比較的早期から認められ, 回 復には約 2 ケ月屯の長期を要するとされてい る ${ }^{2)}$. 腎障害に対する,予防策としては, 投与. 前，中及び投与後の十分な利尿にあり，乙のた めに十分な補液と利尿剂の投与が必要とされて いる，又，腎機能検査による Cisplatin 投与. 


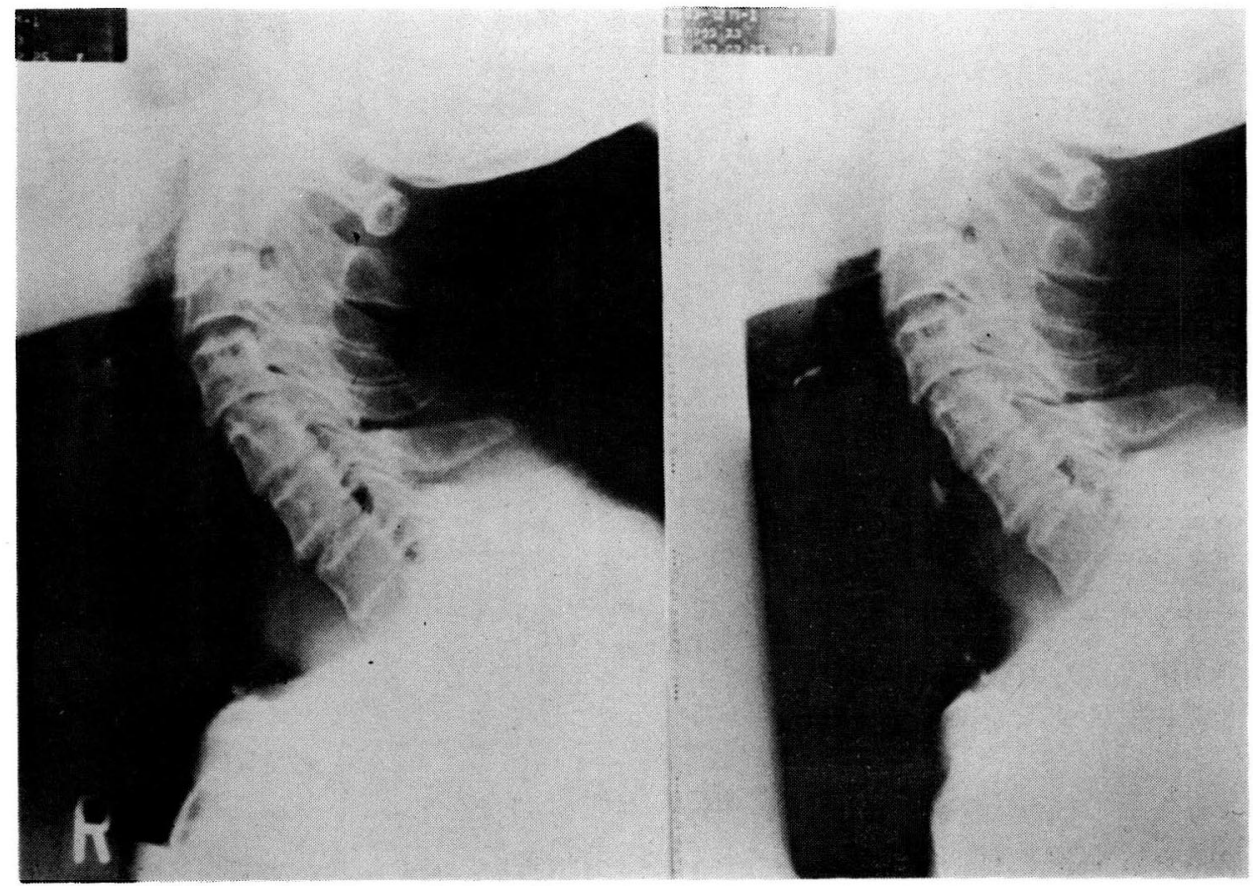

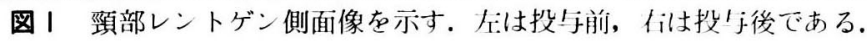

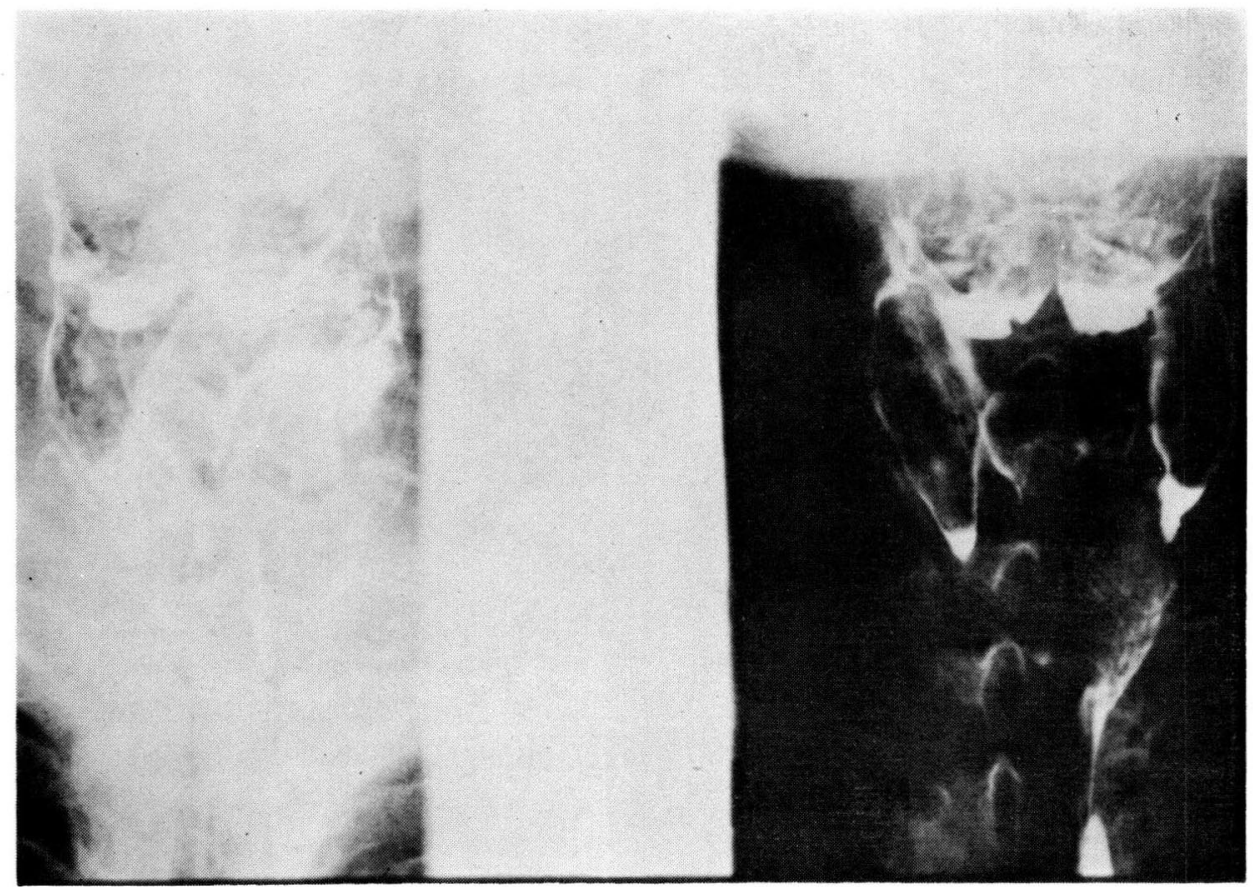

図 2 下咽頭造影正面像を示寸. 左は投与前, 右は投与後である. 


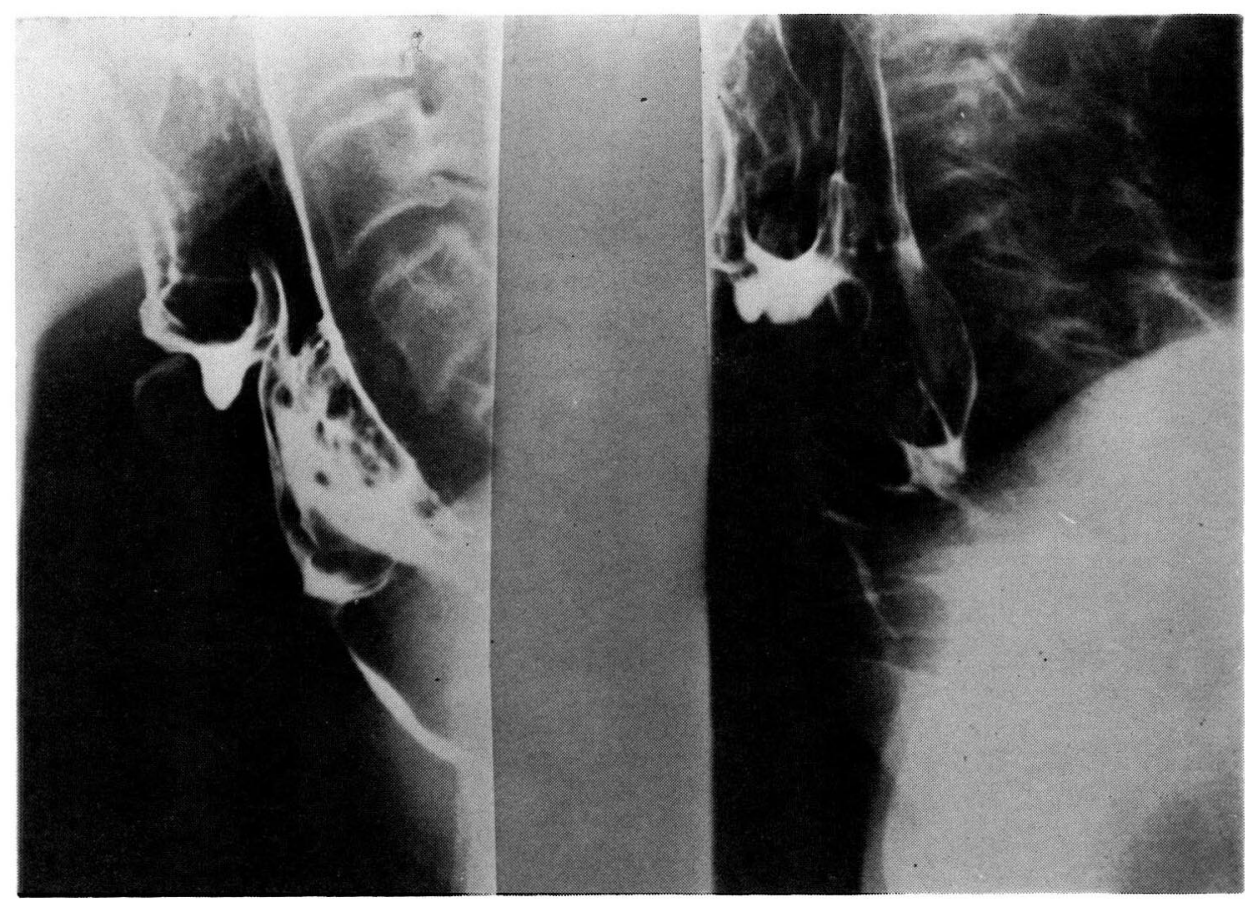

図 3 下咽頭造影側面像を示す，左は投与前，右は投与後である.

表 2

Cisplatin (cis-DDP)の副作用と予防法

(1) 堅障害

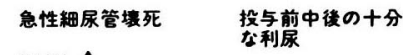

BUN $\uparrow$

クレアチニンけ

Cor $\downarrow$

Psp $\downarrow$

(直後〜2ヶ月)

(2) 造血障害

骨噵抑制

Pancytopenia

告出血

( 2 週問 $\sim 4$ 週間)

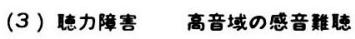

耳鳴

（4）角晹障害昍気

呕吐

\section{利液剧}

感血染防止

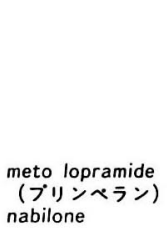

droperidol

量の調節む必要である. 造血障害は全血球系の 隇少を来たし pancytopenia の状態を来たす。

この pancytopenia は, 投与後比較的遅く生
表 3

堅機能

\begin{tabular}{lrrrr} 
& 投与前 & \multicolumn{1}{c}{ 1週目 } & 1ヶ月 & 2ヶ月 \\
$\mathrm{Na}$ & 142 & 137 & 139 & 142 \\
$\mathrm{~K}$ & 3.2 & 3.0 & 4.1 & 3.8 \\
$\mathrm{BUN}$ & 6 & 14 & 15 & 15 \\
$\mathrm{Cr}$ & 0.7 & 1.0 & 0.9 & 0.8 \\
$\mathrm{PSP}(15)$ & 22.3 & 7.9 & & 8.9 \\
$\quad(120)$ & 34.7 & 24.5 & & 37.4 \\
$24 \mathrm{C}$ cr & 70 & 35 & & 52
\end{tabular}

尿所見

$\begin{array}{lllll}\text { 血尿 } & (-) & (-) & (-) & (-) \\ \text { タンバク尿 } & (-) & (-) & (-) & (-)\end{array}$

じ, 回復には $7 \sim 10$ 日間を要し投与後 $4 \sim 5$ 週 目にはほぼ投与前にまで回復するとされてい る. 聴覚障害は耳鳴や特に高音部での感音難聴 が恐められ, 叶気, 叶湢等の消化器障害は必発 とされている3゙.

表 3 には，本症例での腎機能の変化の様子を 経時的に示した。 P S P及び24時間クレアチニ 
ンクリアランス值が投与後約 1 週間目に著明に 低下し 2 ケ月後には，わずかな改善が認められ たものの完全な回復には至らなかった，尚血清

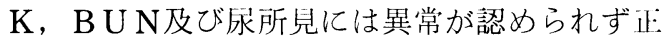
常に保たれており, 腎機能の詳細な検査にはP S P 又は24時間クレアチニンクリアランスが優 れていると思われた。表 4 には, 造血機能の経 過を示した. 投与後 2 週目に pancytopenia が 認められたために輸血と個室での管理を行った ところ 1 ケ月目にはほぼ投与前の状態に回復し た。表 5 には左耳に認められた10-15dbの聴力
の伍化を示したが， 2 ケ月後には改善した。尚 必発と言われている消化器障害は, 本症例では 認められなかった。

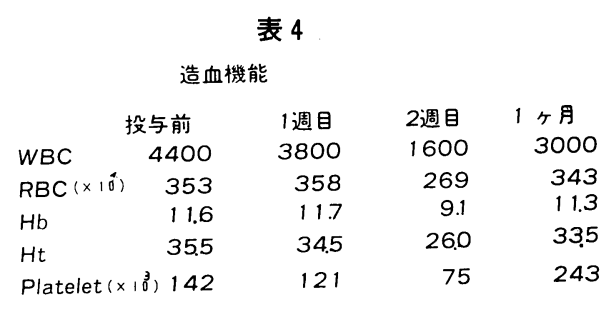

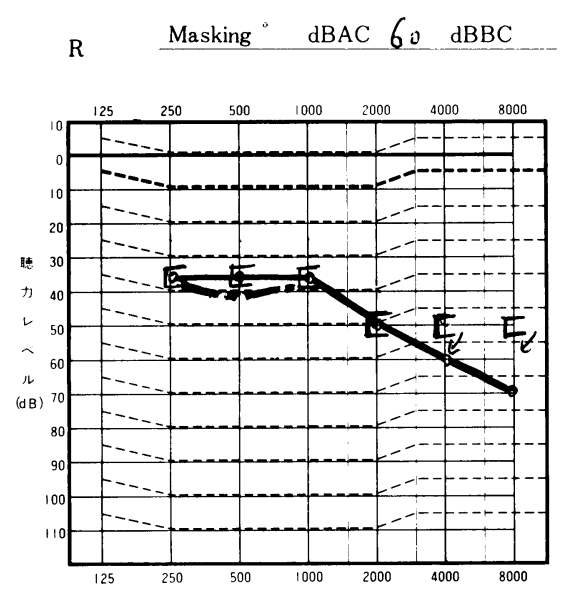

考

1965年ミシガン州立人学 Bernett らが， 1 金笔梳加ら得られた雷父分解液が大腸藏の発育 を阻害することから，白金化合物の抗腫徬作用 が注目され始めた . そして主に泌尿器科領域 ですぐれた抗腫焬俳用が報尘されている。 入そ の作用機序は所諧 Go 期に作用するとされて いる.

最近になり, 站頸部領域での恋性腫瘍に対し ても同様に Cisplatin に優れた抗腫瘍作用のあ ることが明らかにされて米た. James ${ }^{7)}$ は stage

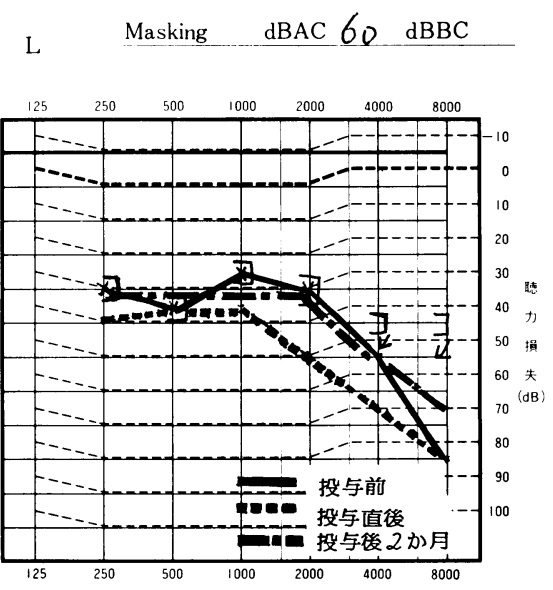

察

III からIVの進行した88例の新鮘な韻頸部腫瘍例 に methotrexate と其に投与し, 術前又は照射 前投与として優れていると報告した. 又 $\mathrm{Shan}^{8)}$ らは, 同じく stage の進んだ新鮮な頭頸部領 域の悪性腫瘍例に対して Bleomycin との併用 投与を113例に行い好成績を得た。 X Victor ${ }^{9)}$ らは, 局所再発又は遠隔転移した崜液腺原発の adenoid cystic carcinoma 7 症例に Cisplatin を単独で投与し疼蛹軽快等の成績を報告した。

Cisplatin の併用楽としては (A) Cisplatin 
単独: Victor B Cisplatin + Bleomycin : Shan, 太田 ${ }^{10)}$, Israël ${ }^{11)}$ (C) Cisplatin $+\mathrm{me}^{-}$ thotrexate: James (D) Cisplatin + Vinblastin + Bleomycin: Einson, Check ${ }^{12)}$ らの方 法が報告されているが，乙れらのう法間で比較 検討した報告はない，又投与量については(イ50 $\mathrm{mg} /$ 月备週投 Shan, \20mg/月条週投与法: James $€ 20 \mathrm{mg}-$ $\mathrm{m}^{2} /$ 日 5 日閒投与法: 太田, Israël らが報告さ れている．即ち投与法については定説はなく，
いずれの方法でも十分な利尿が最大の副作用の 予防方法之され，乙の点が Cisplatin 投与に とり最も重要とされている. James, Shan,

Victor らの報告にあるように，比較的 stage の進んだ症例に対する術前又は照射前の化学療 法として，又，すでに再発，転移を来たした症 例に対する化学療法として, Cisplatin 療法は 優れていると思われる。いずれにせよ，症例を 選び，慎重に投与すれば，一分な効果が期待で きるものと考える.

\section{ま と め}

Cisplatin + PEP が有効であった下咽頭腫瘍例について報告した. そして Cisplatin の投与 法, 有効性及び测作州について，文献的な報告をもとに検討し報告した。

\section{参考 文 献}

1）佐藤武男：咽頭煰一その基儊と臨休一金原出版 1977.

2) Nicolaos, E. M. et al : Platinum nephrotoxicity. The American Journal of Medicine. 65 : 307 312, 1978.

3）日本化薬 参考資料 II 日本化楽株式会社，昭 利154年。

4 ）肥田大：郎，他：Cisplatinum が奏効したと思 われる等丸腫焬の肺転移の一例. H脑X L I . $6: 556 \sim 559,1982$.

5 ) Needleman, S. M. : Basic principles of chemotherapy in the treatment of metastatic head and neck cancer. Ann. Otol. 91:145 $\sim 149,1982$.

6) Einhorn, L.H. : Cisplatinum, vinblastine and bleomycin combination chemotherapy in disseminant testicular cancer. Ann. Intern. Med. $87: 289 \sim 298,1977$.

7) Jame, R.C. et al : Triple therapy for advance cancer of the head and neck. Arch Otolaryngol. $107: 27 \sim 29,1981$.
8) Shan, R.B. et al : Preoperative cisplatin and bleomycin treatment in head and neck squamous carcinoma. Arch Otolaryngol. 107 :683 689, 1891 .

9) Victor, L. S. J. : Cisplatin therapy for adnoid cystic carcinoma. Arch Otolaryngol. 107 : 739 741, 1981.

10）太田和雄 : 肺癌に対するブレオマイシン, シスプ ラチナム併用療法の追試. 第 1 回制癌剤による肺 毒性の防止に関する研究会記録. №. 2 p. $30 \sim 21$, 日本化薬株式会社, 昭和 56 年.

11) Isaël, L. et al : Traitement des cancers épidermoides par bléomycine et platine en administration continue prologée. Nouv. Presse Med. 10:1817 1824, 1981.

12) Check, W. : How do things stand with cisplatin? J.A. M.A. $240: 2521 \sim 2525,1978$.
原稿到着：昭和157年10月25日
別刷請求先：大橋直樹
T930-01 富山市杉谷2630番地
富山医科薬科大学耳鼻咽喉科学教室 